\title{
IDENTIFIKASI KEMAMPUAN BERPIKIR MATEMATIS SISWA MADRASAH ALIYAH DALAM MEMECAHKAN MASALAH MATEMATIKA DITINJAU DARI PROGRAM STUDY
}

\author{
Nailul Munah, Siti Khabibah, Siti Faizah \\ Universitas Hasyim Asy’ari Tebuireng, Jl. Irian Jaya No.55 Jombang Jawa Timur \\ nailulmunah97@gmail.com
}

\begin{abstract}
Abstrak
Penelitian ini merupakan penelitian deskriptif kualitatif yang bertujuan untuk mendeskripsikan kemampuan berpikir matematis siswa kelas XI Madrasah Aliyah (MA) Salafiyah Syafi'iyah Mojokerto dalam memecahkan masalah matematika ditinjau dari program study. Program study yang dimaksud dalam penelitian ini adalah program study regular dan tahfidz. Pemilihan subjek penelitian dilaksanakan berdasarkan teknik pengambilan purposive sampling. Pengelompokan subjek penelitian ini berdasarkan pada kemampuan matematika siswa. Tingkat kemampuan matematika siswa dalam penelitian ini dikategorikan menjadi 3 yaitu kemampuan matematika tinggi, sedang, dan rendah. Selanjutnya dari hasil pengelompokan kemampuan matematika siswa, setiap kelompok tingkat kemampuan matematika diambil satu dari setiap kelasnya. Instrumen yang digunakan untuk mengumpulkan data adalah tes pemecahan masalah dan pedoman wawancara. Hasil penelitian menunjukan bahwa terdapat perbedaan kemampuan berpikir matematis pada siswa program study regular dan tahfidz. Siswa kelas XI MIPA 1 program study tahfidz memiliki kemampuan berpikir matematis dalam memecahkan masalah matematika dapat dibedakan menjadi dua yaitu tinggi dan sedang. Kemampuan berpikir matematis yang tinggi dapat dipenuhi oleh subjek ST-T dan ST-S, dan kemampuan berpikir matematis yang sedang dipenuhi oleh subjek ST-R. Sedangkan kemampuan berpikir matematis siswa kelas XI MIPA 2 program study regular dalam memecahkan masalah matematika dapat dibedakan menjadi tiga sesuai dengan kemampuan matematika yang dimiliki oleh setiap subjek.
\end{abstract}

Kata Kunci: berpikir matematis, pemecahan masalah, program study.

\begin{abstract}
This research was a qualitative descriptive research that aims to describe abilities mathematical thinking in class XI MA Salafiyah Syafi'iyah Mojokerto in solving mathematical problems in terms of program study. The program of study referred to in this studied was a reguler study and tahfidz study. The selection of research subjects was carried out based on the purposive sampling technique. The grouping of research subjects is based on students mathematical abilities. The level of mathematics ability of students in this study was categorized into 3, namely high, medium, and low mathematical abilities. Furthermore, from the results of grouping students' mathematical abilities, each of group level of mathematical ability was taken one from each class. The instruments were used to collect data were problem-solving tests and interview guidelines. The results of the research showed that there were differences in mathematical thinking skills students regular study and tahfidz study. Students of class XI MIPA 1 tahfidz study program had the ability to think mathematically in mathematics problem-solving can be divided into two, high and medium. The ability of high mathematical thinking can be fulfilled by the subjects ST-T and ST-S, and mathematical thinking skills that are being fulfilled by the subject ST-R. While the capacity of students mathematical thinking class XI MIPA 2 regular study program in solving mathematical problems can be divided into three according to the mathematical skills possessed by each subject.
\end{abstract}


Keywords: mathematical thinking, problem-solving, program study.

\section{Pendahuluan}

Matematika adalah ilmu yang dapat mengasah kemampuan logika, berpikir, dan analisis. Sejalan dengan pemikiran Johnson dan Rising (Russefendi, 2006) yang menyatakan matematika adalah pola berpikir, pola mengorganisasikan, dan pembuktian yang logis. Hal tersebut memberikan makna bahwa belajar matematika akan dapat mengarahkan siswa untuk berpikir logis, sistematis, kritis, dan praktis, sehingga dalam aplikasinya siswa dapat lebih peka terhadap permasalahan-permasalahan disekitarnya.

Matematika di Indonesia merupakan salah satu mata pelajaran yang diajarkan pada pendidikan formal dari jenjang Sekolah Dasar (SD) hingga Perguruan Tinggi. Tujuan matematika diajarkan adalah untuk membekali siswa dengan kemampuan berpikir logis, analitis, sistematis, kritis, dan kreatif, serta kemampuan memperoleh, mengelola, dan memanfaatkan informasi untuk bertahan hidup pada keadaan yang selalu berubah. Alasan lainnya sebagaimana disebutkan dalam Depdiknas (2006) diisyaratkan bahwa penalaran (reasoning), pemecahan masalah (problem solving), dan komunikasi (communication) merupakan kompetensi yang harus dikuasai siswa setelah belajar matematika.

Pada proses pemecahan suatu masalah, terjadi proses berpikir sehingga individu dapat menemukan jawaban yang diinginkan. Hudojo (2005) menyatakan bahwa dengan pemecahan masalah individu akan berlatih memproses data atau informasi. Dalam memproses data atau informasi inilah yang disebut berpikir. Pemecahan masalah merupakan dasar dan karakter dalam pembelajaran matematika. Sesuai dengan pendapat Hembree (Lazakidou, 2007) yang menyatakan bahwa problem solving is characterised as an essential and complex activity in mathematics. Sehingga dalam pembelajaran matematika guru diharapkan agar dapat mengembangkan kemampuan pemecahan masalah yang dimiliki siswa.

Menurut Noyes (Wijaya, 2012) dalam pembelajaran matematika, banyak siswa dilatih untuk melakukan perhitungan matematika dibandingkan dengan dididik untuk berpikir matematis. Terdapat perbedaan antara "melakukan perhitungan matematika" dengan "berpikir matematis". Untuk memahami perbedaan keduanya, matematika bisa dilihat dari tiga sudut pandang, yaitu: (1) posisi matematika, (2) aspek matematika, dan (3) jenis pengetahuan matematika. Penempatan matematika sebagai objek merupakan akibat dari pandangan matematika sebagai suatu ilmu tentang atau a science of. Ketika memandang matematika sebagai ilmu tentang, maka kita cenderung hanya bekerja di dalam matematika saja dan fokus pada 
produk matematika saja tanpa memperhatikan aspek sifat dan prinsip matematika, dan itu semua akan menyulitkan kita untuk membangun kemampuan berpikir matematis. Oleh sebab itu kita juga harus menempatkan matematika sebagai alat, sehingga kita tidak hanya memandang matematika sebagai suatu ilmu tentang atau a science of tetapi juga sebagai suatu ilmu untuk atau a science for. Kemampuan berpikir matematis akan mudah dibangun jika guru memberikan penekanan pada sifat dan prinsip matematika, misalnya pada pola dan hubungan.

Menurut Saenz, ada tiga macam pengetahuan dalam matematika, yaitu pengetahuan prosedural, pengetahuan konseptual, dan pengetahuan kontekstual (Wijaya, 2012). Pengetahuan konseptual terkait dengan konsep matematika. Pengetahuan ini harus dikuasai siswa secara bermakna. Pengetahuan konseptual membangun suatu sistem kognitif yang dibutuhkan untuk mengeksekusi algoritma secara benar. Sementara pengetahuan prosedural merupakan pengetahuan tentang bagaimana melakukan suatu prosedur matematika atau algoritma, sedangkan pengetahuan kontekstual berkaitan dengan kemampuan dalam memahami masalah kontekstual yang mencakup kemampuan dalam mengidentifikasi konsep matematika dalam masalah kontekstual, melakukan pemodelan masalah, menyelesaikan masalah secara matematis, sampai dapat menerjemahkan solusi matematis ke dalam solusi real sesuai dengan konteks masalah nyata. Pengembangan kemampuan berpikir matematis memerlukan penekanan pada pengetahuan konseptual dan kontekstual.

Hal tersebut penting untuk diketahui serta dilakukan oleh guru untuk membantu dalam mengklasifikasikan tahap kemampuan berpikir matematis siswa sebagai acuan dalam upaya pengembangan kemampuan pemecahan masalah matematika siswa. Dengan mengetahui tahap kemampuan berpikir matematis siswa, guru dapat melacak letak kesulitan siswa dalam belajar. Kesulitan yang teramati dapat dijadikan sumber informasi sebagai acuan dalam memperbaiki dan mengembangkan kualitas pembelajaran. Hal ini sejalan dengan yang dikemukakan oleh Piaget (Suparno, 2010) bahwa pembelajaran matematika selayaknya disesuaikan dengan perkembangan struktur kognitif dan afektif siswa. Oleh karena itu proses pembelajaran matematika bertahap mulai dari masalah yang konkret dan perlahan-lahan hingga materi yang bersifat abstrak.

Disisi lain pada masa sekarang pendidikan di Indonesia mengalami perkembangan yang cukup pesat dengan adanya banyak keragaman salah satu keragaman tersebut adalah memadukan pendidikan ilmu pengetahuan dengan ilmu agama, yang diharapkan nantinya dapat meningkatkan kualitas hidup manusia. Salah satu contoh keragaman pendidikan di Indonesia adalah megintegrasikan program study yang berupa tahfidzul qur'an kedalam kurikulum sekolah 
yang berbasis umum. Program tahfidzul qur'an yang dulunya hanya sebagai program yang berada di pondok pesantren sekarang banyak dimasukkan sebagai ekstrakurikuler maupun menjadi program study yang masuk kurikulum sekolah tersebut. MA Salafiyah Syafi'iyah di Mojokerto adalah sekolah yang sebelumnya hanya berbasis pada kurikulum umum saja karena sudah berada di lingkungan Pondok Pesantren Tahfidzul Qur'an. Tetapi pada tahun 2016 MA Salafiyah Syafi'iyah membuat suatu formula program study tahfidz khusus yang kemudian dikenal sebagai kelas tahfidz. Program ini diresmikan oleh Menteri Pemuda dan Olahraga Republik Indonesia Dr. H. Imam Nahrawi, S.Ag., M.KP, yang ditujukan sebagai bentuk pengembangan kepemudaan melalui spiritual dengan pendidikan tahfidz. Sehingga jurusan yang semula hanya ada 2 yaitu IPA dan IPS saja, sekarang menjadi 4 yaitu kelas MIPA tahfidz (MIPA 1), IPS tahfidz (IPS 1), MIPA reguler (MIPA 2), dan IPS reguler (IPS 2). Penelitian diambil kelas XI MIPA 1 dan XI MIPA 2 Tahun Ajaran 2018/2019 oleh peneliti.

Salah satu materi di tingkat SMA/MA yang menekankan pada pemecahan masalah adalah program linear. Materi ini merupakan materi yang ada di kelas XI MIPA. Masalah yang sering dirasakan sulit oleh siswa dalam materi program linear adalah dalam menyelesaikan soal cerita. Nafi'an (2011) menyatakan bahwa penyelesaian soal cerita tidak hanya memperhatikan jawaban akhir perhitungan, tetapi proses penyelesaiannya juga harus diperhatikan. Siswa diharapkan menyelesaikan soal cerita dalam program linear melalui suatu proses tahap demi tahap sehingga terlihat alur berpikirnya.

Berdasarkan hasil observasi dan wawancara pada guru matematika kelas IX MIPA yang dilakukan oleh peneliti pada tanggal 15 Desember 2018 di MA Salafiyah Syafi'iyah Mojokerto diperoleh hasil bahwasanya terdapat perbedaan dalam menjawab soal program linear yang sama antara kelas MIPA 1 dan kelas MIPA 2. Jawaban dari siswa kelas XI MIPA 2 program study reguler cenderung lebih ringkas, tanpa ada tahap mengetahui apa yang didapat dari soal dan langsung mencari titik-titik dari persamaan yang didapat tanpa menggambarkan diagram cartesiusnya serta diakhir jawaban tidak memberikan kesimpulan dari jawaban yang didapat. Sedangkan jawaban dari siswa kelas XI MIPA 1 program study tahfidz lebih terinci, dengan berbagai tahap yaitu ditulis apa yang diketahui dari soal, persamaan yang terbentuk dari soal, mencari titik-titik dari persamaan dan menggambarkan dalam diagram cartesiusnya, serta diakhir jawaban memberikan kesimpulan dari penyelesaian yang didapat.

Berdasarkan masalah dan fakta yang telah diuraikan di atas, maka pertanyaan dalam penelitian ini adalah bagaimana kemampuan berpikir matematis siswa kelas XI Madrasah Aliyah dalam memecahkan masalah matematika ditinjau dari program study ?. Kemudian berdasarkan 
pertanyaan penelitian di atas, maka tujuan dalam penelitian ini adalah untuk mendeskripsikan kemampuan berpikir matematis siswa kelas XI Madrasah Aliyah dalam memecahkan masalah matematika ditinjau dari program study.

\section{Metode Penelitian}

Penelitian ini merupakan penelitian deskriptif kualitatif, Menurut Creswell (Sangadji \& Sopiah, 2010) penelitian deskriptif adalah metode penelitian yang berusaha menggambarkan dan menginterpretasikan objek apa adanya (sesuai kondisi sesungguhnya di lapangan). Dalam penelitian ini, kemampuan berpikir matematis subjek diamati berdasarkan hasil mengerjakan tes pemecahan masalah program linear dan hasil wawancara. Sejalan dengan hal itu, peneliti menggolongkan penelitian ini sebagai penelitian dengan pendekatan kualitatif. Sugiyono (2016: 13) mengartikan penelitian kualitatif sebagai metode penelitian yang digunakan untuk meneliti kondisi objek yang alamiah dimana analisis data bersifat induktif/ kualitatif. Pemilihan subjek penelitian dalam penelitian ini berdasarkan teknik pengambilan purposive sampling yaitu pemilihan yang didasarkan pada sebuah tujuan. Pengelompokan subjek penelitian ini berdasarkan pada kemampuan matematika siswa. Penentuan kategori tingkat kemampuan matematika siswa dapat dilihat berdasarkan hasil belajar matematika siswa kelas XI MIPA 1 program study tahfidz dan XI MIPA 2 program study reguler, dan juga tes yang sebelumnya telah didiskusikan dengan guru matematika kelas XI MIPA dan dosen pemebimbing. Tingkat kemampuan matematika siswa dalam penelitian ini dikategorikan menjadi 3 yaitu kemampuan matematika tinggi, sedang, dan rendah. Selanjutnya dari hasil pengelompokan kemampuan matematika siswa, setiap kelompok tingkat kemampuan matematika diambil satu dari setiap kelasnya. Subjek penelitian yang telah terpilih kemudian diberikan tes pemecahan masalah program linear dan wawancara untuk dianalisis kemampuan berpikir matematisnya.

Indikator berpikir matematis yang digunakan dalam penelitian ini adalah indikator berpikir matematis menurut Shafer dan Foster (1997) yang dapat dilihat pada tabel 1.

Tabel 1 Indikator Berpikir Matematis Menurut Shafer dan Foster

\begin{tabular}{|l|l|l|}
\hline \multicolumn{1}{|c|}{ Fase } & \multicolumn{1}{|c|}{ Indikator } & \multicolumn{1}{c|}{ Penjelasan } \\
\hline Reproduksi & a) Mengetahui fakta dasar & $\begin{array}{l}\text { Mengungkapkan dan menuliskan apa yang } \\
\text { diketahui dan apa yang ditanyakan pada soal secara } \\
\text { lengkap. }\end{array}$ \\
\cline { 2 - 3 } & $\begin{array}{l}\text { b) Menerapkan algoritma } \\
\text { standar }\end{array}$ & $\begin{array}{l}\text { Mengaplikasikan kalimat sehari-hari dalam soal } \\
\text { menjadi simbol-simbol dalam matematika dengan } \\
\text { baik }\end{array}$ \\
\hline
\end{tabular}




\begin{tabular}{|c|c|c|}
\hline & $\begin{array}{l}\text { c) Mengembangkan } \\
\text { keterampilan teknis }\end{array}$ & $\begin{array}{l}\text { Menguraikan informasi yang diperoleh dari soal } \\
\text { menjadi bentuk penyelesaian dari soal }\end{array}$ \\
\hline \multirow[t]{4}{*}{ Koneksi } & a) Mengintegrasikan informasi & $\begin{array}{l}\text { Menggabungkan permasalahan soal dengan } \\
\text { karakteristiknya dengan baik }\end{array}$ \\
\hline & $\begin{array}{l}\text { b) Membuat koneksi inter dan } \\
\text { antar domain matematika }\end{array}$ & $\begin{array}{l}\text { Menerjemahkan kalimat pada soal dan menerapkan } \\
\text { kaidah berhubungan dengan informasi soal guna } \\
\text { memperoleh suatu solusi }\end{array}$ \\
\hline & $\begin{array}{l}\text { c) Menetapkan rumus yang } \\
\text { akan digunakan untuk } \\
\text { menyelesaiakan masalah }\end{array}$ & $\begin{array}{l}\text { Menganalisis situasi baru dengan kaidah } \\
\text { sebelumnya untuk menetapkan rumus yang tepat } \\
\text { untuk menyelesaikan soal }\end{array}$ \\
\hline & $\begin{array}{l}\text { d) Memecahkan masalah tidak } \\
\text { rutin }\end{array}$ & $\begin{array}{l}\text { Menyelesaikan permasalahan dengan menggunakan } \\
\text { lebih dari satu pengetahuan }\end{array}$ \\
\hline \multirow[t]{6}{*}{ Analisis } & a) Matematisasi situasi & $\begin{array}{l}\text { Menetapkan langkah yang paling sesuai untuk } \\
\text { kondisi soal }\end{array}$ \\
\hline & b) Melakukan analisis & $\begin{array}{l}\text { Membuat analisa terhadap informasi yang } \\
\text { dibutuhkan untuk menyelesaikan pertanyaan pada } \\
\text { soal sehingga diperoleh suatu suatu solusi yang } \\
\text { tepat }\end{array}$ \\
\hline & c) Melakukan interpretasi & $\begin{array}{l}\text { Menyelesaikan masalah dengan baik hingga } \\
\text { diperoleh jawaban dari pertanyaan soal }\end{array}$ \\
\hline & $\begin{array}{l}\text { d) Mengembangkan model dan } \\
\text { strategi sendiri }\end{array}$ & Membangun penyelesaian sendiri \\
\hline & $\begin{array}{l}\text { e) Mengkomunikasikan } \\
\text { matematika }\end{array}$ & $\begin{array}{l}\text { Menjelaskan penyelesaian yang dilakukan dengan } \\
\text { tepat, baik secara tertulis maupun lisan }\end{array}$ \\
\hline & f) Membuat generalisasi & Membuat kesimpulan terhadap hasil yang diperoleh \\
\hline
\end{tabular}

(Sumber: Shafer dan Foster, 1997 dalam Supriyatno, 2014)

Teknik analisis data yang digunakan dalam penelitian ini ada dua yaitu analisis isi dan analisis model Miles dan Huberman. Teknik analisis isi digunakan untuk menganalisis hasil dari jawaban tes pemecahan masalah sedangkan teknik analisis model Miles dan Huberman digunakan untuk menganalisis jawaban tes pemecahan masalah dan transkip hasil wawancara.

\section{Hasil dan Pembahasan}

Berdasarkan indikator kemampuan berpikir matematis dalam memecahkan masalah matematika menurut Shafer dan Foster pada tabel 2.1, penelitian ini menunjukkan bahwa tidak semua subjek yang diambil dapat memenuhi seluruh indikator berpikir matematis di setiap fase pemecahan masalah. Hasil analisis kemampuan berpikir matematis dalam memecahkan masalah matematika pada program linear selengkapnya akan dijelaskan sebagai berikut: 
1. Kemampuan Berpikir Matematis Siswa Kelas XI MIPA 1 Program Study Tahfidz dalam Memecahkan Masalah Matematika pada Materi Program Linear

Hasil analisis kemampuan berpikir matematis siswa kelas XI MIPA 1 program study tahfidz dalam memecahkan masalah matematika pada materi program linear, dapat dibagi menjadi tiga dengan masing-masing subjek memiliki kemampuan matematika tinggi, sedang, dan rendah. Berikut deskripsi hasil analisis yang telah diperoleh:

a. Siswa Kelas XI MIPA Tahfidz (MIPA 1) dengan Kemampuan Matematika Tinggi (ST-T)

Berdasarkan analisis yang telah dilakukan pada subjek ST-T dari soal pertama dan kedua, diperoleh hasil rincian kemampuan berpikir matematis dalam memecahkan masalah matematika materi program linear. Subjek ST-T memenuhi sebagian besar indikator kemampuan berpikir matematis. Pada fase reproduksi subjek ST-T dapat memenuhi tiga indikator dengan baik. Indikator yang pertama yaitu mengetahui fakta dasar, pada indikator ini subjek mampu menuliskan apa yang diketahui dan ditanyakan pada masalah yang diberikan. Hal ini mengindikasikan bahwa subjek mampu memahami soal dengan baik. Indikator yang kedua adalah menerapkan algoritma standar, subjek ST-T mampu mengubah kalimat pada soal menjadi simbol matematika dengan baik. Indikator ketiga adalah tahap mengembangkan keterampilan teknis, subjek ST-T mampu membuat pertidaksamaan berdasarkan informasi yang diperoleh dari soal secara tepat. Pada fase koneksi dalam memecahkan masalah matematika materi program linear, subjek ST-T mampu memenuhi empat indikator dengan baik. Pada indikator pertama yaitu mengintegrasikan informasi, subjek ST-T mampu menggabungkan pertidaksamaan yang dibuat dengan karakteristiknya untuk menemukan titik ujinya, hal ini mengindikasikan bahwa subjek ST-T telah mampu memahami indiktor yang pertama dengan baik. Selanjutnya indikator yang kedua adalah membuat koneksi inter dan antar domain matematika, subjek ST-T mampu menerjemahkan kalimat pada soal dan menerapkan kaidah berhubungan dengan informasi soal guna memperoleh suatu solusi. Indikator yang ketiga adalah menetapkan rumus yang akan digunakan untuk menyelesaikan masalah, pada tahap ini subjek ST-T mampu menganalisis situasi baru dengan kaidah sebelumnya untuk menetapkan rumus yang tepat untuk menyelesaikan soal. Indikator yang keempat adalah memecahkan masalah tidak rutin, pada indikator ini subjek ST-T mampu menyelesaikan permasalahan dengan menggunakan lebih dari satu langkah penyelesaian diantaranya adalah operasi aljabar dan pemodelan matematika dalam menyelesaian permasalahan yang ada pada soal. Fase analisis adalah fase terakhir dalam memecahkan masalah matematika 
materi program linear, pada fase ini subjek ST-T mampu memenuhi lima indikator dengan baik dan hanya satu indikator yang tidak terpenuhi. indikator pertama yaitu matematisasi situasi, pada indikator ini subjek ST-T mampu menetapkan langkah yang paling sesuai untuk kondisi soal, yaitu menyelesaikan pertidaksamaan dengan eliminasi dan substitusi dengan tepat. Indikator kedua adalah melakukan analisis, subjek ST-T pada indikator ini mampu melakukan analisa terhadap informasi yang dibutuhkan untuk menyelesaikan pertanyaan pada soal sehingga diperoleh suatu solusi yang tepat. Indikator ketiga adalah melakukan interpretasi, subjek ST-T mampu menyelesaikan masalah dengan baik hingga diperoleh jawaban dari pertanyaan pada soal. Indikator keempat adalah mengembangkan model dan strategi sendiri, pada tahap ini subjek hanya mampu membuat penyelesaian sebagaimana yang diajarkan gurunya saja. indikator kelima adalah mengkomunkasikan matematika, pada tahap ini subjek ST-T mampu menjelaskan secara lisan dan tertulis penyelesaian yang dilakukan dengan jelas.indikator keenam adalah membuat generalisasi, pada indikator ini menunjukkan subjek ST-T mampu membuat kesimpulan dari penyelesaian yang telah dilakukan. Hasil penelitian ini didukung oleh penelitian yang dilakukan oleh Putri dan Manoy (2013), yang menyatakan bahwa siswa dengan kemampuan matematika tinggi mampu menyelesaikan hampir semua langkah-langkah dalam pemecahan masalah dengan benar dan tepat. Hasil penelitian ini didukung juga oleh penelitian Hidayati dan Widodo (2015) yang menyatakan bahwa siswa dengan kemampuan matematika tinggi dapat menunjukkan proses pemecahan masalah dan mendapatkan solusi yang tepat.

b. Siswa Kelas XI MIPA Tahfidz (MIPA 1) dengan Kemampuan Matematika Sedang (ST-S)

Berdasarkan analisis yang telah dilakukan pada subjek ST-S dari soal pertama dan kedua, diperoleh hasil rincian kemampuan berpikir matematis dalam memecahkan masalah matematika materi program linear. Pada pembahasan ini, akan dibahas kemampuan berpikir matematis subjek ST-S yang cukup mampu memenuhi sebagian besar indikator kemampuan berpikir matematis. Fase reproduksi yang memiliki tiga indikator yang dapat dipenuhi dengan baik oleh subjek ST-S. Indikator pertama yaitu mengetahui fakta dasar, pada indikator ini subjek mampu menjelaskan kembali soal dengan menggunakan bahasa subjek sendiri, selain itu subjek juga mampu menjelaskan apa yang diketahui dan apa yang ditanyakan dari soal secara lisan. Hal ini mengindikasikan bahwa subjek ST-S mampu memahami soal dengan baik. Selanjutnya indikator kedua adalah menerapkan algoritma standar, subjek ST-S mampu mengubah kalimat pada soal menjadi simbol matematika 
dengan tepat. Indikator ketiga adalah mengembangkan keterampilan teknis, subjek ST-S pada indikator ini mampu membuat pertidaksamaan berdasarkan informasi yang diperoleh dari soal secara tepat. Fase koneksi dalam memecahkan masalah matematika materi program linear ditunjukkan dengan subjek ST-S mampu memenuhi indikator pada fase ini, meskipun tidak semuanya dapat terpenuhi. Pada indikator pertama yaitu mengintegrasikan informasi, subjek ST-S mengatakan bahwa informasi yang ada sudah cukup untuk menjawab pertanyaan pada soal, tetapi pada soal yang kedua subjek masih kurang jelas dalam menggabungkan pertidaksamaan yang dibuat dengan karakteristiknya untuk menemukan titik ujinya. Hal ini mengindikasikan bahwa subjek ST-S cukup mampu memahami permasalahan soal serta karakteristiknya dengan baik. Indikator kedua adalah membuat koneksi inter dan antar domain matematika, subjek ST-S mampu menerjemahkan kalimat pada soal dan menerapkan kaidah berhubungan dengan informasi soal guna memperoleh suatu solusi. Indikator ketiga adalah menetapkan rumus yang akan digunakan untuk menyelesaikan masalah, pada indikator ini subjek ST-S mampu menganalisis situasi baru dengan kaidah sebelumnya untuk menetapkan rumus yang tepat dalam menyelesaikan soal. Indikator keempat adalah memecahkan masalah tidak rutin, pada indikator ini subjek mampu menyelesaikan permasalahan dengan menggunakan lebih dari satu langkah penyelesaian diantaranya adalah operasi aljabar dan pemodelan matematika dalam menyelesaian permasalahan yang ada, tetapi subjek ST-S hanya mampu melakukan indikator ini pada soal yang kedua. Keempat indikator pada fase koneksi bisa dipenuhi subjek ST-S dengan tepat hanya pada dua indikator saja sebab masing-masing dari dua soal yang diberikan ada satu indikator yang tidak terpenuhi. Fase analisis adalah fase terakhir dalam memecahkan masalah matematika materi program linear, pada fase ini subjek ST-S mampu memenuhi satu indikator dengan baik sedangkan kelima indikator di soal yang pertama tidak terpenuhi dan di soal yang kedua hanya ada dua indikator yang tidak terpenuhi. Indikator pertama yaitu mematematisasi situasi, pada indikator ini subjek ST-S mampu menetapkan langkah yang paling sesuai untuk kondisi soal, yaitu menyelesaikan pertidaksamaan dengan eliminasi dan substitusi dengan tepat. Indikator kedua adalah melakukan analisis, ST-S pada indikator ini mampu melakukan analisa terhadap informasi yang dibutuhkan untuk menyelesaikan pertanyaan pada soal sehingga diperoleh suatu solusi yang tepat, namun hanya pada soal yang kedua. Indikator ketiga adalah melakukan interpretasi, subjek ST-S mampu menyelesaikan masalah dengan cukup baik sehingga diperoleh jawaban dari pertanyaan pada soal, namun hanya terpenuhi di soal 
yang kedua. Indikator keempat adalah mengembangkan model dan strategi sendiri, pada indikator ini subjek hanya mampu membuat penyelesaian sebagaimana yang telah diajarkan gurunya saja. Indikator kelima adalah mengkomunikasikan matematika, subjek ST-S pada indikator ini mampu menjelaskan secara lisan dan tertulis penyelesaian yang dilakukan dengan jelas pada soal yang kedua saja. Indikator keenam adalah membuat generalisasi, pada indikator ini menunjukkan subjek ST-S belum membuat kesimpulan dari jawaban yang diperoleh karena di soal yang pertama belum selesai dan di soal yang kedua lupa. Hasil penelitian ini bertolak belakang dengan penelitian yang dilakukan oleh Putri dan Manoy (2013), yang menyatakan bahwa siswa dengan kemampuan matematika sedang cukup mampu menyelesaikan langkah-langkah dalam pemecahan masalah dengan benar dan tepat. Hasil penelitian ini juga bertolak belakang dengan penelitian Hidayati dan Widodo (2015) yang menyatakan bahwa siswa dengan kemampuan matematika sedang dapat menunjukkan proses pemecahan masalah dan mendapatkan solusi tepat namun dalam tahap penyelesaiannya ada beberapa proses yang kurang terpenuhi.

c. Siswa Kelas XI MIPA Tahfidz (MIPA 1) dengan Kemampuan Matematika Rendah (ST$\mathrm{R})$

Berdasarkan analisis yang telah dilakukan pada subjek ST-R dari soal pertama dan kedua, diperoleh hasil rincian kemampuan berpikir matematis dalam memecahkan masalah matematika materi program linear. Pada pembahasan ini, akan dibahas kemampuan berpikir matematis subjek ST-R, yang cukup mampu memenuhi indikator berpikir matematis. Pada fase reproduksi subjek ST-R dapat memenuhi tiga indikator dengan tepat, baik di soal pertama maupun kedua. Indikator pertama yaitu mengetahui fakta dasar, pada indikator ini subjek ST-R mampu menjelaskan apa yang diketahui dan apa yang ditanyakan dari soal secara lisan maupun tulisan. Hal ini mengindikasikan bahwa subjek mampu memahami soal dengan cukup baik. Selanjutnya adalah indikator kedua yaitu menerapkan algoritma standar, subjek ST-R mampu mengubah kalimat pada soal menjadi simbol matematika dengan tepat. Indikator ketiga adalah mengembangkan keterampilan teknis, subjek ST-R pada indikator ini mampu membuat pertidaksamaan berdasarkan informasi yang diperoleh dari soal secara tepat. Fase koneksi dalam memecahkan masalah matematika ditunjukkan dengan subjek ST-R mampu memenuhi empat indikator pada fase koneksi, tetapi pada fase ini subjek ST-R hanya mampu memenuhi dua indikator dengan tepat di soal yang pertama dan kedua. Indikator yang dapat terpenuhi adalah indikator pertama yaitu mengintegrasikan informasi, subjek ST-R mengatakan bahwa informasi 
yang ada sudah cukup untuk menjawab pertanyaan pada soal dan dapat menggabungkan pertidaksamaan yang dibuat dengan karakteristiknya untuk menemukan titik ujinya. Indikator kedua yaitu membuat koneksi inter dan antar domain matematika, subjek ST-R mampu menerjemahkan kalimat pada soal dan menerapkan kaidah berhubungan dengan informasi soal guna memperoleh suatu solusi.Fase analisis subjek ST-R dalam memecahkan masalah terlihat dari enam indikator berpikir matematis. Pada fase ini subjek ST-R belum mampu memenuhi semua Indikator yang ada, baik soal yang pertama maupun yang kedua. Hasil penelitian ini bertolak belakang dengan penelitian yang dilakukan oleh Putri dan Manoy (2013), yang menyatakan bahwa siswa dengan kemampuan matematika rendah belum mampu menyelesaikan langkah-langkah dalam pemecahan masalah dengan benar dan tepat. Hasil penelitian ini juga bertolak belakang dengan penelitian Hidayati dan Widodo (2015) yang menyatakan bahwa siswa dengan kemampuan matematika rendah hanya dapat menunjukkan dua proses pemecahan masalah dan belum mendapatkan solusi.

2. Kemampuan Berpikir Matematis Siswa Kelas XI MIPA 2 Program Study Reguler dalam Memecahkan Masalah Matematika pada Materi Program Linear

Hasil analisis kemampuan berpikir matematis siswa kelas XI MIPA 2 program study reguler dalam memecahkan masalah matematika pada materi program linear, dapat dibagi menjadi tiga dengan masing-masing subjek memiliki kemampuan matematika tinggi, sedang, dan rendah. Berikut deskripsi hasil analisis yang telah diperoleh:

a. Siswa Kelas XI MIPA Reguler (MIPA 2) dengan Kemampuan Matematika Tinggi (SR-T)

Berdasarkan analisis yang telah dilakukan pada subjek SR-T dari soal pertama dan kedua, diperoleh hasil rincian kemampuan berpikir matematis dalam memecahkan masalah matematika materi program linear. Pada pembahasan ini, Subjek SR-T memenuhi sebagian besar indikator kemampuan berpikir matematis. Pada fase reproduksi subjek SR-T dapat memenuhi tiga indikator dengan tepat, baik di soal pertama maupun kedua. Indikator pertama yaitu mengetahui fakta dasar, pada indikator ini subjek SR-T mampu menjelaskan kembali soal dengan menggunakan bahasa subjek sendiri, selain itu subjek juga mampu menjelaskan apa yang diketahui dan apa yang ditanyakan dari soal. Hal ini mengindikasikan bahwa subjek SR-T mampu memahami soal dengan baik. Indikator yang kedua adalah menerapkan algoritma standar, subjek SR-T mampu mengubah kalimat pada soal menjadi simbol matematika dengan tepat. Indikator ketiga adalah mengembangkan keterampilan teknis, subjek SR-T pada indikator ini mampu membuat pertidaksamaan berdasarkan informasi yang diperoleh dari soal secara tepat. Fase koneksi dalam 
memecahkan masalah matematika materi program linear ditunjukkan dengan subjek SR-T mampu memenuhi empat indikator dengan baik, meskipun ada satu indikator yang tidak terpenuhi. Pada indikator pertama yaitu mengintegrasikan informasi, subjek mengatakan bahwa informasi yang ada sudah cukup untuk menjawab pertanyaan pada soal tapi ketika menggabungkan pertidaksamaan yang dibuat dengan karakteristiknya untuk menemukan titik ujinya subjek tidak menuliskan dengan baik di lembar jawaban yang tersedia, hal ini mengindikasikan bahwa subjek SR-T mampu memahami permasalahan soal serta karakteristiknya dengan baik. Indikator kedua adalah membuat koneksi inter dan antar domain matematika, subjek SR-T mampu menerjemahkan kalimat pada soal dan menerapkan kaidah berhubungan dengan informasi soal guna memperoleh suatu solusi. Indikator ketiga adalah menetapkan rumus yang akan digunakan untuk menyelesaikan masalah, pada indikator ini subjek SR-T mampu menganalisis situasi baru dengan kaidah sebelumnya untuk menetapkan rumus yang tepat dalam menyelesaikan soal. Indikator keempat adalah memecahkan masalah tidak rutin, pada indikator ini subjek mampu menyelesaikan permasalahan dengan menggunakan lebih dari satu langkah penyelesaian, diantaranya adalah operasi aljabar dan pemodelan matematika dalam menyelesaian permasalahan yang ada pada soal. Fase analisis subjek SR-T dalam memecahkan masalah matematika materi program linear terlihat dari enam indikator yang ada.indikator pertama yaitu mematematisasi situasi, pada indikator ini subjek mampu menetapkan langkah yang paling sesuai untuk kondisi soal, yaitu menyelesaikan pertidaksamaan dengan eliminasi dan substitusi dengan tepat. Indikator kedua adalah melakukan analisis, SR-T pada indikator ini mampu melakukan analisa terhadap informasi yang dibutuhkan untuk menyelesaikan pertanyaan pada soal sehingga diperoleh suatu solusi yang tepat. Indikator ketiga adalah melakukan interpretasi, subjek SR-T mampu menyelesaikan masalah dengan baik hingga diperoleh jawaban dari pertanyaan pada soal. Indikator keempat adalah mengembangkan model dan strategi sendiri, pada indikator ini subjek hanya mampu membuat penyelesaian sebagaimana yang diajarkan gurunya saja. Indikator kelima adalah mengkomunkasikan matematika, subjek SR-T pada indikator ini mampu menjelaskan secara lisan dan tertulis penyelesaian yang dilakukan dengan jelas. Indikator terakhir adalah membuat generalisasi, pada indikator ini menunjukkan subjek SR-T mampu membuat kesimpulan dari penyelesaian yang telah dilakukan. Dari keenam indikator yang dimiliki oleh fase analisis dapat terlihat bahwa subjek SR-T memenuhi lima indikator dengan baik dan hanya ada satu indikator yang kurang terpenuhi baik di soal yang pertama 
maupun kedua.Hasil penelitian ini didukung oleh penelitian yang dilakukan oleh Putri dan Manoy (2013), yang menyatakan bahwa siswa dengan kemampuan matematika tinggi mampu menyelesaikan hampir semua langkah-langkah dalam pemecahan masalah dengan benar dan tepat. Hasil penelitian ini didukung juga oleh penelitian Hidayati dan Widodo (2015) yang menyatakan bahwa siswa dengan kemampuan matematika tinggi dapat menunjukkan proses pemecahan masalah dan mendapatkan solusi yang tepat.

b. Siswa Kelas XI MIPA Reguler (MIPA 2) dengan Kemampuan Matematika Sedang (SRS)

Berdasarkan analisis yang telah dilakukan pada subjek SR-S dari soal pertama dan kedua, diperoleh hasil rincian kemampuan berpikir matematis dalam memecahkan masalah matematika materi program linear. Pada pembahasan ini, akan dibahas kemampuan berpikir matematis subjek SR-S, yang cukup mampu memenuhi sebagian besar indikator berpikir matematis. Pada fase reproduksi subjek SR-S dapat memenuhi tiga indikator dengan tepat, baik di soal pertama maupun kedua. Indikator pertama yaitu mengetahui fakta dasar, pada indikator ini subjek SR-S mampu menjelaskan apa yang diketahui dan apa yang ditanyakan dari soal secara lisan. Hal ini mengindikasikan bahwa subjek mampu memahami soal dengan cukup baik. Selanjutnya adalah indikator kedua yaitu menerapkan algoritma standar, subjek SR-S mampu mengubah kalimat pada soal menjadi simbol matematika dengan tepat. Indikator ketiga adalah mengembangkan keterampilan teknis, subjek SR-S pada indikator ini mampu membuat pertidaksamaan berdasarkan informasi yang diperoleh dari soal secara tepat. Fase koneksi dalam memecahkan masalah matematika ditunjukkan dengan subjek SR-S mampu memenuhi empat indikator pada fase koneksi, tetapi pada fase ini subjek SR-S hanya mampu memenuhi satu indikator dengan tepat di soal yang pertama dan kedua. Pada soal yang pertama subjek SR-S mampu memenuhi dua indikator sedangkan di soal yang kedua subjek SR-S mampu memenuhi tiga indikator. Indikator pertama yaitu mengintegrasikan informasi, subjek SR-S mengatakan bahwa informasi yang ada sudah cukup untuk menjawab pertanyaan pada soal, tetapi pada soal yang kedua subjek masih kurang jelas dalam menggabungkan pertidaksamaan yang dibuat dengan karakteristiknya untuk menemukan titik ujinya. Hal ini mengindikasikan bahwa subjek SR-S cukup mampu memahami permasalahan soal serta karakteristiknya dengan baik. Selanjutnya adalah indikator kedua yaitu membuat koneksi inter dan antar domain matematika, subjek SR-S mampu menerjemahkan kalimat pada soal dan menerapkan kaidah berhubungan dengan informasi soal guna memperoleh 
suatu solusi. Indikator ketiga adalah menetapkan rumus yang akan digunakan untuk menyelesaikan masalah, pada indikator ini subjek SR-S mampu menganalisis situasi baru dengan kaidah sebelumnya untuk menetapkan rumus yang tepat dalam menyelesaikan soal, tapi hanya pada soal yang kedua. Indikator keempat adalah memecahkan masalah tidak rutin, pada indikator ini subjek mampu menyelesaikan permasalahan dengan menggunakan lebih dari satu langkah penyelesaian, namun hanya mampu melakukan indikator ini pada soal yang kedua.Fase analisis subjek SR-S dalam memecahkan masalah terlihat dari enam indikator berpikir matematis. Pada fase ini subjek SR-S hanya mampu memenuhi satu indikator di soal yang kedua yaitu pada indikator mematematisasi situasi, sedangkan di soal yang pertama subjek SR-S belum mampu memenuhi enam indikator yang ada pada fase analisis.Hasil penelitian ini didukung oleh penelitian yang dilakukan oleh Putri dan Manoy (2013), yang menyatakan bahwa siswa dengan kemampuan matematika sedang cukup mampu menyelesaikan langkah-langkah dalam pemecahan masalah dengan benar dan tepat. Hasil penelitian ini didukung juga oleh penelitian Hidayati dan Widodo (2015) yang menyatakan bahwa siswa dengan kemampuan matematika sedang dapat menunjukkan proses pemecahan masalah dan mendapatkan solusi tepat namun dalam tahap penyelesaiannya ada beberapa proses yang kurang terpenuhi.

c. Siswa Kelas XI MIPA Reguler (MIPA 2) dengan Kemampuan Matematika Rendah (SR$\mathrm{R})$

Berdasarkan analisis yang telah dilakukan pada subjek SR-R dari soal pertama dan kedua, diperoleh hasil rincian kemampuan berpikir matematis dalam memecahkan masalah matematika materi program linear. Pada pembahasan ini, akan dibahas kemampuan berpikir matematis subjek SR-R, yang cukup mampu memenuhi indikator berpikir matematis. Pada fase reproduksi subjek SR-R dapat memenuhi dua indikator dengan tepat, baik di soal pertama maupun kedua. Indikator pertama yaitu mengetahui fakta dasar, pada indikator ini subjek SR-R mampu menjelaskan apa yang diketahui dan apa yang ditanyakan dari soal secara lisan maupun tulisan. Hal ini mengindikasikan bahwa subjek mampu memahami soal dengan cukup baik. Selanjutnya adalah indikator kedua yaitu menerapkan algoritma standar, subjek SR-R mampu mengubah kalimat pada soal menjadi simbol matematika dengan tepat. Indikator ketiga adalah mengembangkan keterampilan teknis, subjek SR-R pada indikator ini mampu membuat pertidaksamaan berdasarkan informasi yang diperoleh dari soal secara tepat, tapi hanya pada soal yang kedua. Fase 
koneksi dalam memecahkan masalah matematika ditunjukkan dengan empat indikator. Pada fase ini subjek SR-R hanya mampu memenuhi satu indikator dengan tepat di soal yang pertama dan kedua, dengan rincian soal yang pertama ada dua indikator yang terpenuhi dan di soal yang kedua hanya satu indikator yang terpenuhi. Indikator yang dapat terpenuhi adalah indikator pertama yaitu mengintegrasikan informasi, subjek SR-R menyatakan bahwa informasi yang ada sudah cukup untuk menjawab pertanyaan pada soal. Indikator kedua yang terpenuhi oleh soal yang pertama adalah membuat koneksi inter dan antar domain matematika, subjek SR-R mampu menerjemahkan kalimat pada soal dan menerapkan kaidah berhubungan dengan informasi soal guna memperoleh suatu solusi. Fase analisis subjek SR-R dalam memecahkan masalah terlihat dari enam indikator berpikir matematis. Pada fase ini subjek SR-R belum mampu memenuhi semua Indikator yang ada, baik di soal yang pertama maupun yang kedua. Hasil penelitian ini didukung oleh penelitian yang dilakukan oleh Putri dan Manoy (2013), yang menyatakan bahwa siswa dengan kemampuan matematika rendah belum mampu menyelesaikan langkahlangkah dalam pemecahan masalah dengan benar dan tepat. Hasil penelitian ini didukung juga oleh penelitian Hidayati dan Widodo (2015) yang menyatakan bahwa siswa dengan kemampuan matematika rendah hanya dapat menunjukkan dua proses pemecahan masalah dan belum mendapatkan solusi.

\section{Simpulan dan Saran}

Berdasarkan hasil penelitian yang dilaksanakan oleh peneliti terhadap enam subjek, dengan rincian tiga siswa berasal dari kelas XI MIPA 1 program study tahfidz dan tiga siswa berasal dari kelas XI MIPA 2 program study reguler serta memiliki kemampuan matematika masing-masing tinggi, sedang, dan rendah di setiap kelasnya diperoleh simpulan sebagai berikut, kemampuan berpikir matematis siswa kelas XI MIPA 1 program study tahfidz dalam memecahkan masalah matematika pada materi program linear dapat dibedakan menjadi dua yaitu tinggi dan sedang. Kemampuan berpikir matematis yang tinggi dapat dipenuhi oleh subjek ST-T dan ST-S, sedangkan kemampuan berpikir matematis yang sedang dipenuhi oleh subjek ST-R. Sedangkan kemampuan berpikir matematis siswa kelas XI MIPA 2 program study regular dalam memecahkan masalah matematika pada materi program linear dapat dibedakan menjadi tiga sesuai dengan kemampuan matematika yang dimiliki oleh setiap subjek yaitu tinggi, sedang, dan rendah. 
Berdasarkan hasil pembahasan yang diperoleh, maka peneliti mengajukan beberapa saran sebagai berikut, bagi guru yang telah mengetahui kemampuan matematika dari masing-masing siswa adalah, guru dapat membiasakan siswa dengan kemampuan matematika tinggi, sedang dan rendah untuk menyelesaikan masalah matematika dengan menuliskan apa yang diketahui dan apa yang ditanyakan, terampil untuk menganalis masalah, dan menyelesaikan masalah secara lengkap. Dan bagi siswa dengan kemampuan matematika tinggi, sedang dan rendah dapat lebih termotivasi lagi untuk menyelesaikan masalah matematika. Selain itu, siswa harus terbiasa untuk menyelesaikan masalah matematika dengan menggunakan fase-fase berpikir matematis.

\section{Referensi}

Amir, Zubaidah dan Risnawati. 2016. Psikologi Pembelajaran Matematika. Yogyakarta: Aswaja Pressindo.

Badan Standar nasional Pendidikan. 2006. Standar Isi Untuk Satuan Pendidikan Sekolah Menegah Atas. Jakarta: Badan Standar Nasional Pendidikan (BNSP).

Bungin, Burhan. 2003. Analisis Data Penelitian Kualitatif. Jakarta: PT Raja Grafindo Persada.

Hudojo, Herman. 2005. Mengajar Belajar Matematika. Jakarta: Depdikbud

Kline, Morris. 1973. Why Jonhny Can't Add: The Failure of the New Math. New York: Vintage Books.

Lazakidou, G. 2007. "The Transitory Phase to The Attainment of Self-regulatory Skill in Mathematical Problem Solving". International Education Journal 8(1): 71-81. Shannon Research Press.

Nafi'an, Muhammad Ilman. 2011. “Kemampuan Siswa dalam Menyelesaikan Soal Cerita Ditinjau dari Gender di Sekolah Dasar". Prosding Seminar Nasional Matematika dan Pendidikan Matematika FMIPA UNY.

National Council of Teachers of Mathematics. 2000. Principles anda Standards for School Mathematics. Reston, VA: National Council of Teachers of Mathematics. [Online] http://www.NCTM.ORG/ [ Diakses tanggal 16 Desember 2018 ]

Russefendi, E.T. 2006. Pengantar Kepada Membantu Guru Mengembangkan Kompetensinya dalam Pengajaran Matematika untuk Meningkatkan CBSA. Bandung: Tarsito.

Sangadji, Etta Mamang, \& Sopiah. 2010. Metodologi Penelitian Pendekatan Praktis Pada Penelitian. Yogyakarta: Andi.

Shadiq, Fajar. 2004. Pemecahan Masalah, Penalaran dan Komunikasi. Yogyakarta: Widyaiswara PPPG Matematika.

Shafer, M.C., \& Foster , S. 1997. The Changing Face of Assesment. Principled Practice In Mathematic \& Science Education. Paper 1 No. 2.

Sugiyono. 2016. Metode Penelitian Pendidikan Kuantitatif, Kualitatif Dan R\&D. Bandung: CV. Alfa Beta

Supriyatno, Agus. 2014. "Karakteristik Berpikir Matematis Siswa SMP Majelis Tafsir Al-Quran (MTA) Gemolong Dalam Memecahkan Masalah Matematika Pada Materi SPLDV 
Ditinjau Dari Kemampuan Penalaran Siswa Dan Gender". Jurnal Elektronika Pembelajaran Matematika, Vol. 2, No. 10: 1056-1068.

Wijaya, Ariyadi. 2012. Pendidikan Matematika Realistik, Suatu Alternatif Pendekatan Matematika. Yogyakarta: Graha Ilmu. 